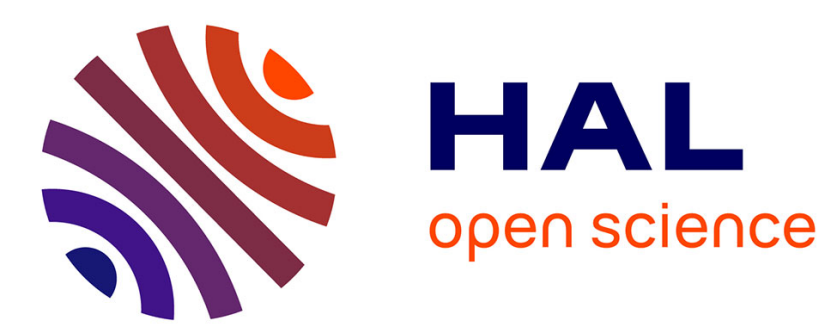

\title{
The Nolan Street of Pompeii in Chapter VI of Das Templum by Heinrich Nissen
}

\author{
Amelia Carolina Sparavigna
}

\section{To cite this version:}

Amelia Carolina Sparavigna. The Nolan Street of Pompeii in Chapter VI of Das Templum by Heinrich Nissen. 2021. hal-03249473

\section{HAL Id: hal-03249473 \\ https://hal.science/hal-03249473}

Preprint submitted on 4 Jun 2021

HAL is a multi-disciplinary open access archive for the deposit and dissemination of scientific research documents, whether they are published or not. The documents may come from teaching and research institutions in France or abroad, or from public or private research centers.
L'archive ouverte pluridisciplinaire HAL, est destinée au dépôt et à la diffusion de documents scientifiques de niveau recherche, publiés ou non, émanant des établissements d'enseignement et de recherche français ou étrangers, des laboratoires publics ou privés. 


\title{
The Nolan Street of Pompeii in Chapter VI of Das Templum by Heinrich Nissen
}

\author{
Amelia Carolina Sparavigna \\ Department of Applied Science and Technology, Politecnico di Torino
}

In the Chapter VI of a book by Heinrich Nissen, entitled Das Templum, 1869, we can find the author claiming the Nolan Street of Pompeii had been aligned according to the sunrise on summer solstices. Here we discuss how Nissen justified his thought. We will see in particular his point of view about the orientation according to sunrise as rebuked by Hyginus. In the discussion, we will also mention the observations made by Ferdinando Castagnoli on Nissen's Das Templum and by Stefano De Caro on the orientation of the Nolan Street.

Torino, June 4, 2021

\section{Introduction}

Heinrich Nissen, in a book entitled Das Templum ${ }^{1}$ (1869) [1], proposed an analysis of the orientation of temples, military camps (castra) and towns, according to the sunrise. Of his thought, and in particular of his proposal linking the orientation of the decumanus, the main street of a town or a camp, to the foundation day we discussed in [2]. Nissen's work had been criticized, as reported in [2], in particular for the fact that he saw the presence of a quadripartite templum when the town was deduced. Let us note that the solar orientation in Roman world has been discussed in a very careful manner by J. Le Gall $[3,4]$. A detailed discussion of Das Templum has been made by Giulio De Petra in his review of Nissen's book [5].

Of the decumanus, Nissen is talking in Chapter VI of the book [1]. And there we find the discussion of Nolan Street of Pompeii. Nissen claims that this street has been oriented to the sunrise on summer solstice. However, there is a problem, the alignment is not a perfect one, because of the natural horizon. It could be a possible orientation if we consider the astronomical horizon [6].

We know that Roman surveyors mentioned several orientations of the subdivision of land (centuriation) [3]. There is the orientation according to North-South and EastWest geographic directions, which was considered the perfect one. Then we find orientations according to sunrise, to the widest range of the land, coastline and mountain ranges, and according to the presence of main roads. By means of a solar orientation, "aiming at the rising sun, at the point of the horizon at which the sun

1 A Templum is an open space for augural observation. From it, the temple, a place dedicated to a deity, a sanctuary. 
appears on a given day, then the decumanus is determined by simply lengthening the line found on the groma to both sides", as told by Nissen himself. However, in this case, the Nolan Street is not oriented to the sunrise.

This problem about the role of horizon, probably, induced Nissen to discuss the orientation of decumani, in a manner that he defined as new. He considers a passage by Hyginus, where Hyginus rebuked the solar orientation, proposing an opinion which is different from those of other scholars ( "There we find a Niebuhr that sees it as "proof of the rawness of the local Roman surveyors", Rudorff on the ignorance of the Mensores"). By his new reading of Hyginus, using also the question about the surveying of a land where hills are present, Nissen seems to move to an ideal orientation, according to an astronomical horizon. However, he is not clear at all in explaining his approach. In any case, after reading Nissen's words, it seems that for the German scholar, it is the orientation according to sunrise that has to be considered. And in this framework, he can claim a Pompeii oriented according to solstices.

\section{The Nolan Street in maps}

Before continuing the discussion of Nissen's Das Templum, let us stress that solar orientations, according to natural or astronomical horizon, is one of the orientations mentioned by Roman surveyors. As we can see from the following maps, based on elevation data from satellites, the orientation of Pompeii streets is perfect for the local terrain.

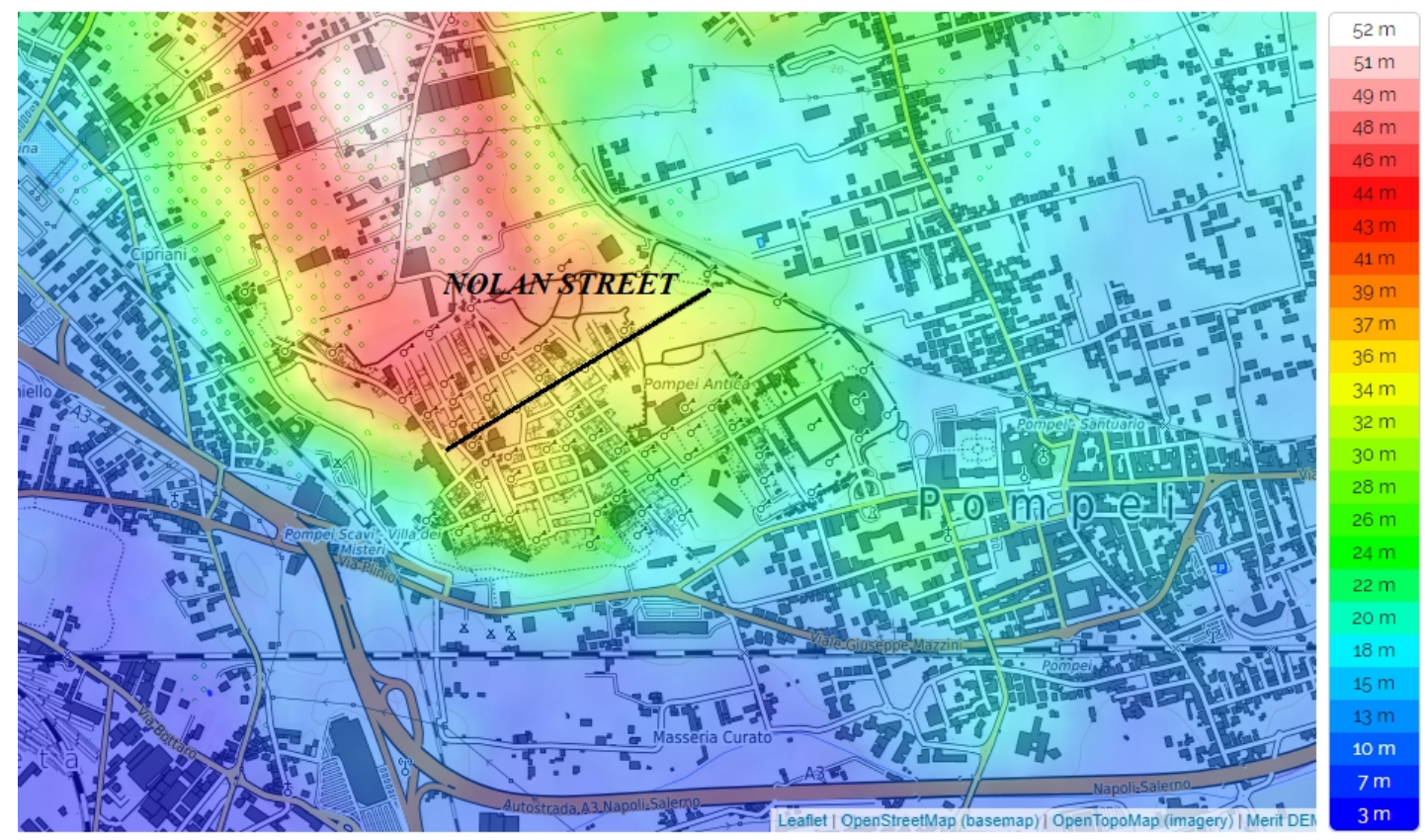

Fig.1 - Pompeii in the map offered by https://it-ch.topographic-map.com . Many thanks to the site for the precious instrument, based on the works by Yamazaki D., D. Ikeshima, R. Tawatari, T. Yamaguchi, F. O'Loughlin, J.C. Neal, C.C. Sampson, S. 


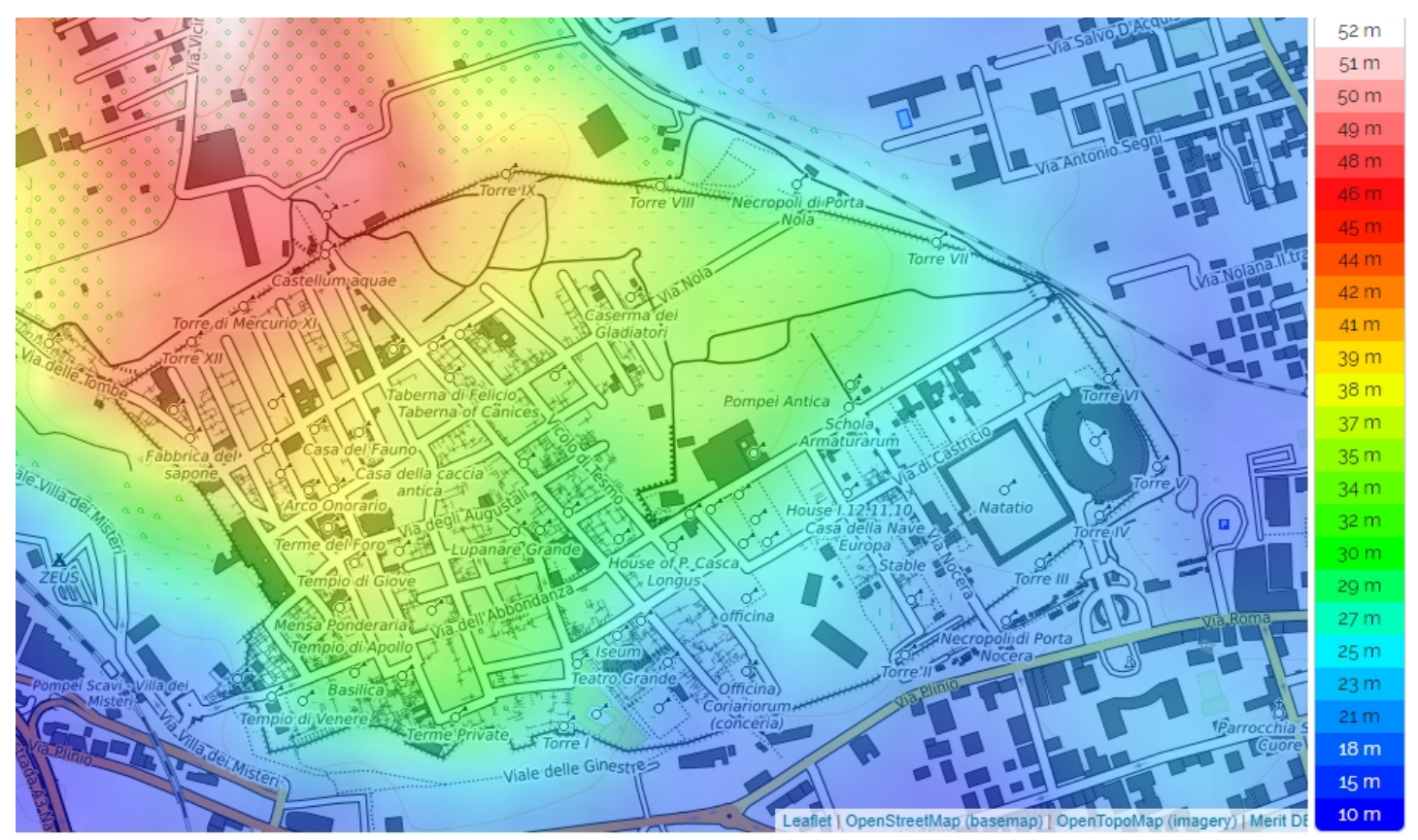

Fig.2 - As in the Figure 1, Pompeii in the map offered by https://it-ch.topographicmap.com . Many thanks to the site for the precious instrument, based on the works by Yamazaki D., D. Ikeshima, R. Tawatari, T. Yamaguchi, F. O'Loughlin, J.C. Neal, C.C. Sampson, S. Kanae \& P.D. Bates (2017) [7].

\section{The axial system}

As we can see from the images given above, the urban layout of Pompeii is based on an axial system. Of this system, Ferdinando Castagnoli discussed in [8]. This Reference is important to understand the framework of Nissen's theory, and also to see that his theory has been criticized, besides by Giulio De Petra and by Martin Erdmann [9], by Valeton and Thulin too [10,11]. Here some excerpts from [8]. We can find Nissen, when Ferdinando Castagnoli is discussing the Etruscan and Italic cities. In particular, the discussion is concerning the use and origin of their axial layout.

Castagnoli tells that axial layouts are found at Veio and certainly at Pompeii, in its archaic nucleus, probably of Italic origin. Therefore, the axial system was known in the Etrusco-Italic world; however a more complex layout, such as that observed in Marzabotto, is the result of a direct Greek influence (about Marzabott, [12]). The presence of the axial system for town-planning had been noted by Haverfield and von Gerkan as being characteristic of the Italic people. Yet - Castagnoli tells - we must point out that the axial system is also found in Greece, that it has no prehistory and 
that, once perfected, found widespread use in the Roman world.

However, the axial system is not found in Rome itself, as Varro supposed: dictaque primum est Roma quadrata, quod ad aequilibrium foret posita, that is bounded and delineated by means of the groma. Following Varro, several scholars have attempted, unsuccessfully, to find cardine and decumanus on the Palatine Hill.

Castagnoli continues considering a special significance that surrounded the use of the axial system. For the Etruscans, it is told that it was coming from a relation between terrestrial delimitation and the celestial templum. "The heavens were like a circle divided into four parts by two axes. The cardine and decumanus as employed in city planning were an earthly representation of the heavenly pattern. Further delineations within the four sectors determined the distribution of the seats of the gods (known principally through Martianus Capella). These arrangements within the four sectors were closely tied to the art of reading omens by the quadrant in which lightning is seen and to augury, as seen by the subdivisions of the entrails of Piacenza, inscribed with the names of gods appropriate to each. The various sectors were probably also linked to the flight of birds. The Etruscans, however, unlike the Romans and Umbrians, left no trace of this art".

Castagnoli continues mentioning the different orientation of the Templum that we can find in the ancient literature. "Unfortunately, the evidence concerning the orientation of the templum is contradictory". Then we find Varro, Livy, Dionysius of Halicarnassus, Plutarch, Servius, Vitruvius "who according to Nissen draws from Hellenistic sources", recommending to face west. "This orientation is the one the gromatici knew, for they favored the west not only for the orientation of the temple but especially for base lines for land surveys". However, we find also a northern orientation in Greek world and Etruscans who did favour a southerly orientation.

Castagnoli considers also the theories of surveyors. "In the cities and in the agri centuriati, the orientation system is different. The base line here is east-west. There is no doubt that the doctrines of the gromatici are abstract speculations that have artificially superimposed cosmic theories on standard surveying practice. However, it appears exaggerated to believe that these doctrines were formulated by Varro, based on the Hellenistic theories of westerly orientation of the temples, as Barthel maintains. Nor can we say, as Weinstock maintains, that there was no link between the art of surveying and the theories of the cosmos. Contrary to the usual statements, there are examples of oriented centuriation; it must also be noted that the centuriation was designed after the groma with auspices had been placed. Having made these qualifications, we must nevertheless agree in relating the theorizing of the gromatici to the erudition of the late Republic. In particular, the system of urban and agrarian delimitation has nothing in common with the templum, as is seen even in the fact of east-west orientation rather than north-south".

"But it is the city that interests us particularly. The theories of K. O. Müller and Nissen of a city being a templum have been justly denied by Valeton and by Thulin. Although the founding of the city occurred according to an Etruscan ritual, inauguratio urbis dealt with tracing the walls, not with patterning the city itself, as Valeton observes". And Castagnoli continues the discussion about the templum and the mundus in particular. "Although the founding of the city occurred according to an 
Etruscan ritual, inauguratio urbis dealt with tracing the walls, not with patterning the city itself, as Valeton observes. ... Likewise, there is much doubt about an element always considered fundamental to the supposed urban templum, and that is the mundus in the city center. At Ostia, Calza for one proposes to find the mundus at the crossing of the cardine and decumanus. However, if there is any one thing clear from the texts, as Hedlund especially has shown, it is that the mundus has nothing to do with the rites of founding the city. In fact, the mundus at Rome was a cavern sacred to Ceres and the Mani, and there is no source that places it on the Palatine".

\section{Chapter VI of Das Templum}

In the following text, the reader can find what Nissen tells at the beginning of Chapter VI of his Das Templum

In the previous chapters, the doctrine of the Templum has been discussed in its essential historical and political significance. It remains to show, in the same manner, how can the understanding of Italic religion be conditioned. We start from the question concerning how the heavenly regions were observed and considered by the Disciplina (Lehre). We are entering an area whose existence is hardly known and which is one of the darkest and, let us say, quite hopeless considered in all the ancient studies. Let us hope, however, that further advanced investigations will gradually shed more light on this area too.

The normal camp is a Templum oriented to the east. It was also found that the town temples of Pompeii and Rome face the same part of the world. It is connected with this [orientation], that the surveyors draw the decumanus, their main line dividing the land, in the same direction. However a question arises, according to which principle the decumanus was drawn, by means of which the specific direction of this main axis, and the whole Templum resting on it, was determined. Actually the direction from east to west coincides, as a whole, with sunrise and sunset and the natural division of the world, but it is required to understand how largely the latitudes are influencing it.

We have, after the literature, that Surveyors distinguish three different systems. The first takes no account of the regions of the sky, but depends on the shape of the land to be measured; according to its linear expansion, the decumanus is placed. It could easily happen that the kardo ran to the east and the decumanus to the south: Hygin $p$. $170^{2}$ et quidam ne proximarum coloniarum limitibus ordinatos limites mitterent, relicta caeli ratione mensuram constituerunt, qua tantum modus centuriarum et limitum longitudo constaret. quidam agri longitudinem secuti: et qua longior erat, fecerunt decimanum ( ibidem p . 178 ) . quidam in totum converterunt, et fecerunt decimanum in meridianum et kardinem in orientem; sicut in agro Campano qui est circa Capuam. The given example is due to a differing view, according to which the east - west line is regarded as kardo and the meridian as decumanus (p. 13). The subtle difference that exists between it and the normal procedure will be clear later. First of all, it is clear that the Limites must be drawn according to the same principles in both cases. In general, the Gromatici are well aware of the religious consecration on which their art is based, at least in an obscure manner. In their point of view, the Limites stand in direct relation to the order of the world: Kardo represents the axis of

2 https://latin.packhum.org/loc/1266/4/0\#0 
the world and Decumanus divides the world in two halves. For this reason, they hold firmly the direction of Decumanus from east to west and of Kardo from south to north. They are referring to the regions of the sky by means of Kardo, the meridian $\left(0^{\circ}=360^{\circ}-180^{\circ}\right)$, and Decumanus, the equinoctial line $\left(270^{\circ}-90^{\circ}\right.$, cf. Plin. N. H. 18, 331: after the kardo, determined as a meridian line, it continues per hunc medium traversa currat alia. haec erit ab exortu aequinoctiali ad occasum aequinoctialem, et limes qui ita secabit agrum decumanus vocabitur).

Practically, [the surveyors] always start from determining the meridian (see p. 14) and place the decumanus on it at right angles. Herein it lies a certain contradiction to the theoretical meaning of the two lines. If Decumanus is the first and most noble line, one might think that the course of Kardo should have been determined according to it, while the practice takes the opposite manner.

In fact there is a third way of drawing the Limites, which proceeds directly from the Decumanus itself. The main points are as follows: Frontin p. 31 optima ergo ac rationalis agrorum constitutio est cuius decumani ab oriente in occidentem diriguntur, kardines a meridiano in septentrionem. Multi mobilem solis ortum et occasum secuti variarunt hanc rationem. sic utique effectum est, ut decumani spectarent ex qua parte sol eo tempore, quo mensura acta est, oriebatur. p . 103 nam et alibi limites facti sunt ab his qui solis ortum et occasum secuti sunt. quos fefellit ratio geometriae . mihi tamen, sicut Higenus constitui decrevit limites, ita rationabile videtur, ut decumanus maximus in orientem crescat et cardo maximus in meridianum. In more detail, Hygin p . 170 multi ignorantes mundi rationem solem sunt secuti, hoc est ortum ac occusum, quod is semel ferramento conprehendi non potest. quid ergo? posita auspiculiter groma, ipso forte conditore praesente, proximum vero ortum conprehenderunt, et in utramque partem limites emiserunt, quibus kardo in horam sextam non convenerit .

Here, the procedure was rebuked as follows: in the middle point of the territory to be measured or the town to be founded (conditore praesente), where the decumanus should run and - as must be concluded from the camp (p. 27) - in the place where the kardo should cut it, the surveyor' instrument is set up. Aiming at the rising sun, at the point of the horizon at which the sun appears on a given day, then the decumanus is determined by simply lengthening the line found on the groma to both sides. The place where the sun rises in different seasons changes by around $65^{\circ}$ in Italy. From it, it follows, first, that the meridian can only intersect the decumanus at right angles if it has been determined by chance around one of the two equinoxes; in all other cases, either the kardo is not at right angles on the decumanus, or if it is, it does not correspond to the meridian line. This is the quibus kardo in horam sextam non convener is referring to.

In a procedure such as the one here criticized, the limitation systems in the various parts of Italy and Roman Empire would necessarily have to be very different, from Hyginus p . 182 multi ita ut supra diximus solis ortum et occasum conprehenderunt, qui est omni tempore mobilis nec potest secundum cursum suum conprehendi, quoniam ortus et occasus signa a locorum natura varie ostenduntur. sic et limitum ordinatio hac ratione conprehensa semper altera alteri dis convenit. hos qui ad limites constituendos hac ratione sunt usi, fefellit mundi magnitudo, qui se ortum et occasum pervidere crediderunt: aut forte scierunt errorem et neglexerunt, ei contenti tantum regioni ortum et occasum demetiri . 
The efforts of the surveyors are resolutely directed towards the application of a specific limitation scheme within the entire Orbis Romanus; conformity is achieved by establishing the practice on meridians everywhere, and in all cases. One may first recognize some external considerations in this tendency, in order to have the limitation simpler, more regulated and more uniform. However, it is not just a practical reason: in fact, we can also find expressed the greatest historical fact the antiquity had known. Since Augustus' time the culture of Mediterranean basin had been enclosed into a single political system as a whole; the Templum, which once upon the Palatine Hill had been limited, had expanded in increasingly wider circles, and now [at the time of the Empire], the last and largest Templum had been established.

However, just as the Templum of an individual town is based on a single decumanus and kardo, not tolerating different figures in comparison, so the same principle is applied consistently and necessarily to the whole empire. The contested procedure stands in open contract. Hyginus p. 183 also directs another reason against the same thing: namely, it is not possible to apply rationally it at all, in the practice; because for a land with hills it is often not possible to grasp the rising or setting line [of the sun] with the diopter. The rising or setting observed in this way is also only an apparent one. The true one cannot even be detected from the top of the world. The true surveyor bases his art on the cosmic worldview: $\mathrm{p}$. 183 quaerendum est primum quae sit mundi magnitudo, quae ratio oriundi aut occidendi, quanta sit mundo terra . advocandum est nobis gnomonices summae ac divinae artis elementum : explicari enim desiderium nostrum ad verum nisi per umbrae momenta non potest .

The practice of orienting the decumanus according to sunrise is attested by the surveyors as a widespread practice, and their ardent polemics go well with this. In the register of towns, Luceria is named as measured according to this principle (p. 210); that just this example is here occurring is a fact that should not be surprising, because most of the measurements date from a comparatively later time.

The question now is how to explain this custom. Niebuhr (R. G. 2, 703) sees it as "proof of the rawness of the local Roman surveyors", Rudorff S. 348 on the ignorance of the Mensores. Certainly it is neither the one nor the other: perhaps there may be educated people in our large cities today who have no idea that the sun rises in a different spot every day; no more in ancient times, in Italy and in a time poor in culture. The surveyors only accuse the practice of having no idea of the size of the world. In any case, it comes from a very old time; a time when people's consciousness knew nothing of the unity of lands, but where an individual in his town recognized a self-contained, political and sacred entity, a world of its own.

Furthermore, a higher consecration rests above the marking out of the decumanus: the groma is set up auspicaliter, i.e. after questioning the will of gods, the founder himself is present, and, as we can see, the ceremony marks the founding day of the Templum. The decumanus corresponds to the direction in which the first rays of the rising sun are falling: p. 183 immo contendisse feruntur ortum eum esse singulis regionibus unde primum sol appareat, occasum ubi novissime desinat: hactenus dirigere mensuram laboraverunt .

This explanation, which necessarily follows from the words of gromatici, opens up a 
completely new way of looking at these things. Like every human being, god and the god's dwelling place, the Templum in its various applications have a birthday in general. This also applies to the town: some birth years of Italians towns are S. 56 put together. As little as we know about this, our sources seem even poorer when it comes to birthdays. For Rome it is given by the festival of Parilies on 21. April, for the Colony of Brundisium [13], it is given through the festival of Salus on the Quirinal on 5. August. According to what has been said above, the direction of the Decumanus corresponds to the sunrise on foundation day of the Templum. And to apply this theory to given cases, the foundation day can be found in the Decumanus, or if the day is known, the direction of Decumanus can be determined. If a conclusion correctly follows from the other in this discussion, then, it was true. First of all, it is interesting to try it out for some specific cases, to understand whether this manner of looking at things might be of any interest for the study of the ruins that are still existing.

According to a request of mine, R. Schöne observed the sunrise in Pompeii in June 1867 in order to establish empirically the period of the year in relation to Pompeii Decumanus, and found that the longest day was the only one on which the Nolan Street could be oriented. He writes the 20th June 1867: Unfortunately there is little to answer your recent questions. A few days ago the sun rose so far south that I very much doubt whether its point of rise will fall northern in the direction of Nolan Street: tomorrow, on the longest day, I want to go back to sunrise and maybe I can add the result of my observation. A pencil note as a postscript: 21 . June early $51 / 2$ o'clock. I am just back from Pompeii. The sun really shines in the Nolan Street today, but in such a way that the south side remains in the shade. Since it rises behind a mountain, it would be ideally this starting point that would fall almost exactly in the direction of the road. So it is certain that the solstice is the only day that is more or less suitable. As far as, my friend: his description illustrates Hyginus's misgivings p. 183 et si kardo a monte non longe nascatur sive decimanus, quomodo potest cursus conprehendi recte, cum ferramento sol occiderit et trans montem adhuc luceat et eisdem ipsis adhuc campis in ulteriore parte resplendeat? Incidentally, the empirical observation has been fully confirmed by exact compass measurements made later.

Like S. 64 tells, the decumanus does not form a perfectly straight line, but the measurements made on different parts of it vary between $234^{\circ}$ and $242^{\circ} 30^{\prime}$. The azimuth of the rising on Solstice is $237^{\circ} 18^{\prime}$ for year $300,237^{\circ} 15^{\prime}$ for the year 600 BC. The direction of the Nolan Street from the Quadrivium, that is the point where the Groma is thought to be placed in this case, to the east, is $236^{\circ}$. The slight deviation of $11 / 4^{\circ}$ may be attributed to the above-mentioned local obstacle, and detailed investigations on the spot would perhaps make it possible to determine where the groma was standing. But in relation to this vanishing difference, there can be no doubt that the Decumanus of Pompeii was really based on Solstice. The Solstice, the 24th June according to the Roman calendar, is one of the most significant days in the natural religions: magnus hic anni cardo, magna res mundi was told by Pliny $\mathrm{N}$. H . 18,264 . It is enough to consider our Midsummer Festival and the related Olympiad celebration to understand.

In Rome it was the day of Fors Fortuna consecrated to the city tyche by Servius Tullius (cf. Preller, Röm. Myth. 2. 553). It is not far from the assumption that the 
Templum of the Servian city was oriented accordingly. Assuming the theory just now proposed, a special religious consecration rests on sunrise and sunset. Both form the main sections in what we call a day; the Babylonians began their civil day with the rise, the Athenians with the fall (Plin. N. H. 2, 188. Censorin 23, 3). The Romans calculated their civil day from midnight, but it was nonetheless the natural day the basis of all time measurement and division. If one thinks out of our modern civilization, which in many cases destroys natural life and the feeling of nature, then there is actually no need for a long argument as to why the times of rise and fall were regarded as particularly sacred. In order to prove that they played the most prominent part as such in the ancient cult, some evidence may follow. ...

[Nissen provides several passages from ancient literature about the role of sunrise. After further discussions, the Chapter ends as follow].

Besides the sun, there are also to consider the rises of the moon and individual stars of particular light intensity, such as Sirius and Venus, that have influenced the direction of the axis of temples, and this is possible and in itself believable. Hopefully, more advanced research will succeed in locating these moments and making them more precise. At present, the only thing that matters is to prove our main theorem. To that extent, I leave aside all further theoretical discussions and turn to the facts on which my assertions are based. You can note that legitimate doubts the reader is facing here, can be raised. And also, a few basic facts about the orientation of the Templum can only be empirically derived from the proposed material.

\section{A friend in Nolan Street}

Before the publication of his book in 1869, Nissen searched for evidence of the relevance of solstices in the planning of ancient towns. "It is enough to consider our Midsummer Festival and the related Olympiad celebration to understand". However, Olympic Games were based on a lunisolar calendar, according to the full moon after the summer solstice. Then it was the moon, not the sun, to rule the time, and the same was true when the orientation of the Nolan Street had been determined.

In 1867, Nissen asked a friend to visit Pompeii.

"According to a request of mine, R. Schöne observed the sunrise in Pompeii in June 1867 in order to establish empirically the period of the year in relation to Pompeii Decumanus, and found that the longest day was the only one on which the Nolan Street could be oriented. He writes the 20th June 1867: Unfortunately there is little to answer your recent questions. A few days ago the sun rose so far south that I very much doubt whether its point of rise will fall northern in the direction of Nolan Street: tomorrow, on the longest day, I want to go back to sunrise and maybe I can add the result of my observation. A pencil note as a postscript: 21 . June early $51 / 2$ o'clock. I am just back from Pompeii. The sun really shines in the Nolan Street today, but in such a way that the south side remains in the shade. Since it rises behind a mountain, it would be ideally this starting point that would fall almost exactly in the direction of the road. So it is certain that the solstice is the only day that is more or less suitable".

Then, instead of finding an agreement with sunrise on solstice, that is the decumanus corresponding to the direction in which the first rays of the rising sun are falling, the 
friend noted that the south side of the street remains in the shade. Nissen, and according to the suggestion of his friend, solved by means of his new interpretation of Hyginus's misgivings.

In fact, we have to observe that Nissen's friend noted the presence of a mountain (Monte Torrenone). Of this mountain, in [14], it is told the following "Già Stefano De Caro aveva infatti potuto sottolineare la forte valenza simbolica di un elemento esterno a Pompei per la defi nizione del tracciato viario: il monte Torrenone, una delle punte più alte dei Monti del Sarno. Secondo l'ipotesi di De Caro questa montagna, ai piedi del quale sgorga un altro elemento vitale per Pompei, il fiume Sarno, presso il quale è stato rinvenuto un santuario ellenistico, sarebbe il punto di riferimento utilizzato per tracciare uno degli assi maggiori della topografi a di Pompei, la Via di Nola." Stefano De Caro stressed the strong symbolic value of an external element, fundamental to define the layout of the streets of Pompeii, It is the Mount Torrenone, one of the highest points of Sarno Mountains. According to De Caro's hypothesis [15], this mountain, at the foot of which we find flowing river Sarno, another vital element for Pompeii, and where a Hellenistic sanctuary existed, would be the reference point used by Pompeii surveyors, to trace one of the major axes of the town, the Via di Nola.

"Questa intuizione del De Caro risulta ancora più interessante se consideriamo che questo stesso punto, il Monte Torrenone, guardato dalla Via di Nola al solstizio d'estate, risulta coincidente con il punto in cui sorge il sole. Questa particolarità era già stata notata da $\mathrm{H}$. Eschebach ma rigettata dallo stesso De Caro, scettico riguardo ad un possibile orientamento astronomico della città" [14]. De Caro's intuition is even more interesting, - Ref. 14 tells - if we consider that this same point, Mount Torrenone, viewed from the Via di Nola at the summer solstice, coincides with the point where the sun is rising. This peculiarity had already been noted by $\mathrm{H}$. Eschebach but rejected by De Caro himself, doubtful about a possible astronomical orientation of the city.

Eschebach noted the alignment a century after Nissen. And let us stress that the sun is not rising over the mountain, it is rising beyond the mountain. We have seen how Nissen arranged the method to conclude for an astronomical orientation. In any case, the proposal by De Caro, of an orientation according to landmarks, is coherent with local environment and surveying methods.

\section{References}

[1] Nissen, H. (1869). Das Templum, antiquarische Untersuchungen, mit astronomische Hülfstafeln von B. Tiele. Weidmannsche Buchhandlung, Berlin.

[2] Sparavigna, Amelia Carolina, Heinrich Nissen and the Orientation of the Templum (May 9, 2021). Available at SSRN Electronic Journal: https://ssrn.com/abstract $=3841521$

[3] Le Gall J. (1975). Les romains et l'orientation solaire. MEFRA 1975 - 87 - 1, p. 
287-320.

[4] Sparavigna, Amelia Carolina, What the Latin Literature Truly Tells Us About the Orientation of Camps, Towns and Centuriation (August 6, 2020). SSRN Electronic Journal. doi http://dx.doi.org/10.2139/ssrn.3675354

[5] Giulio De Petra. Giornale degli Scavi di Pompei (nuova serie), Maggio-Giugno 1869. Recensione del Das Templum.

[6] Sparavigna, Amelia Carolina, The Town Planning of Pompeii and Herculaneum Having Streets Aligned Along Sunrise on Summer Solstice (June 30, 2016). SSRN Electronic Journal. doi http://dx.doi.org/10.2139/ssrn.2802439.

[7] Yamazaki D., D. Ikeshima, R. Tawatari, T. Yamaguchi, F. O'Loughlin, J.C. Neal, C.C. Sampson, S. Kanae \& P.D. Bates (2017). A high accuracy map of global terrain elevations. Geophysical Research Letters, vol. 44, pp. 5844 - 5853, 2017 doi: 10.1002/2017GL072874

[8] Castagnoli, Ferdinando (1971). Orthogonal town planning in antiquity, Cambridge, Mass., MIT Press.

[9] Erdmann, Martin (1883). Zur Kunde der hellenistischen Städtegründungen, Strassburg

[10] Valeton, I. M. J. (1892). De templis romanis. Mnemosyne, 338-390; Valeton, I. M. J. (1893). De templis Romanis (Continued). Mnemosyne, 62-440.

[11] Thulin, C. O. (1906). Die etruskische Disciplin.Die Etruskische Disciplin V1-2: Die Blitzlehre Und Die Haruspicin, Nuova Edizione. Kessinger Publishing, LLC (April 18, 2010)

[12] Sparavigna, Amelia Carolina. (2021). Dalla Marzabotto di Francis John Haverfield alla Neapolis di Kainua. DOI: https://doi.org/10.5281/zenodo.4734428

[13] Sparavigna, Amelia Carolina. (2020, November 2). Brindisi e il suo giorno natale, tra cronologia ed astronomia. Zenodo. DOI https://doi.org/10.5281/zenodo.4077380

[14] Zanella, Sandra (2019). Pompei. Sulle tracce di fondazione e di rifondazioni urbane. Rivista di studi pompeiani : XXX, 7-21. L'Erma di Bretschneider

[15] De Caro, Stefano (1992). Lo sviluppo urbanistico di Pompei. Atti e Memorie Della Società Magna Grecia, 3, 67-90. 